\title{
COMMENTARY
}

\section{Erythropoietin and organ protection: lessons from negative clinical trials}

Ronald G Pearl

See related research by Kim et al., http://ccforum.com/content/17/5/R254

\begin{abstract}
Based on its pleiotropic effects, erythropoietin can decrease inflammation, oxidative stress, and apoptosis. Erythropoietin provides organ protection for the heart, brain, and kidney in diverse preclinical animal studies, especially models that include ischemia-reperfusion injury and/or inflammation. However, large clinical studies in coronary reperfusion, heart failure, stroke, acute kidney injury, and chronic renal disease have failed to demonstrate improved outcomes. A study in a previous issue of Critical Care examining the ability of erythropoietin to prevent or ameliorate acute kidney injury in patients undergoing complex valvular heart surgery is similarly negative. The failure of erythropoietin in clinical studies may be due to an inadequate dose, since the receptors responsible for organ protection may require higher concentrations than those responsible for erythropoiesis. However, as has occurred in studies in sepsis and acute respiratory distress syndrome, the negative studies probably reflect an inadequate understanding of the complexity of the underlying processes with multiple redundant and interacting pathways that may differ among the large number of different cell types involved. As tools to understand this complexity and integrate it on an organismal basis continue to evolve, we will develop the ability to use erythropoietin and related nonhematopoietic agents for organ protection.
\end{abstract}

Correspondence: rgp@stanford.edu

Department of Anesthesiology, Perioperative and Pain Medicine, Stanford University School of Medicine, 300 Pasteur Drive, Room H3589, Stanford, CA 94305-5640, USA 
Erythropoietin has been studied for brain, heart, and kidney protection [2]. Erythropoietin improves survival in neurons during hypoxia in cell culture, animal studies demonstrate protection against ischemia, and initial clinical trials suggested protection in ischemic stroke, but larger trials did not confirm benefits and even suggested adverse outcomes [3]. For the heart, animal studies demonstrate protection after ischemia-reperfusion, and small clinical studies demonstrated benefit in the setting of percutaneous coronary intervention for myocardial infarction. However, large clinical trials did not demonstrate benefits $[4,5]$. Similarly, trials in patients with anemia and heart failure do not demonstrate improved outcomes and raise concerns about increased complications [6,7]. Aggressive use of erythropoietin for treatment of anemia in patients with renal disease or malignancy has also failed to demonstrate benefits [8-10].

The story of erythropoietin use for renal protection has been similar. Animal data demonstrate protective effects, especially in the setting of ischemia-reperfusion injury [2]. However, clinical studies in renal transplantation and chronic kidney disease have been negative [11]. AKI occurs in response to renal ischemia and inflammation and increases morbidity, hospital length of stay, and short-term and long-term mortality. AKI occurs in approximately one-half of patients undergoing cardiac surgery. The anti-oxidant, anti-inflammatory, and anti-apoptotic effects of erythropoietin suggest it may be effective in preventing or ameliorating AKI in this setting. In a pilot study by $\mathrm{Oh}$ and colleagues, erythropoietin decreased AKI and mortality in patients undergoing coronary artery bypass surgery [12]. However, in the study by Kim and colleagues and in another large cardiac surgery study [13], erythropoietin did not decrease the incidence of AKI, did not improve outcome, and did not decrease markers of inflammation. These negative data are consistent with the EARLYARF trial where erythropoietin did not prevent or ameliorate the course of AKI in ICU patients with elevated urinary biomarkers for renal injury [14].

Erythropoietin may have failed in clinical trials due to insufficient dose. Preclinical studies have frequently used doses in the range of 1,000 to $5,000 \mathrm{IU} / \mathrm{kg}$, an order of magnitude higher than the dose of $300 \mathrm{IU} / \mathrm{kg}$ used in many clinical studies. Although this lower dose is adequate for erythropoiesis, the erythropoietin receptors responsible for organ protection are different. Higher doses of erythropoietin could be used but may have adverse effects such as thrombosis and hypertension. One future approach may be the use of nonhematopoietic derivatives such as carbamylated erythropoietin that produce cellular and organ protection in animal studies.

Although dose may be an issue, the multiple negative clinical studies suggest that our approach and understanding of renal, cardiac, and neurologic problems is too simplistic. There is a complex interplay between vascular abnormalities and inflammatory mediators, there are a myriad of different cell types involved, and, within each individual cell, there are complex interactions among multiple pathways that each have redundancy. In this setting (and similarly in sepsis and acute respiratory distress syndrome), the net impact of an intervention that itself has pleiotropic effects becomes unpredictable, resulting in negative clinical trials. For example, erythropoietin is considered to be anti-inflammatory but can worsen inflammation-induced injury in other studies $[15,16]$. Effective use of erythropoietin for organ protection will require a better understanding of the relevant processes that occur at the cellular level [17] and the ability to phenotype individual patients for relevant factors that may affect outcome. With increased knowledge, erythropoietin may become an important weapon for preventing AKI, but it will not be a magic bullet.

\section{Abbreviation}

AKI: Acute kidney injury.

\section{Competing interests}

The author declares that he has no competing interests.

\section{Published online: 11 September 2014}

\section{References}

1. Kim JH, Shim JK, Song JW, Song Y, Kim HB, Kwak YL: Effect of erythropoietin on the incidence of acute kidney injury following complex valvular heart surgery: a double blind, randomized clinical trial of efficacy and safety. Crit Care 2013, 17:R254.

2. Moore EM, Bellomo R, Nichol AD: Erythropoietin as a novel brain and kidney protective agent. Anaesth Intensive Care 2011, 39:356-372.

3. Ehrenreich $H$, Weissenborn $K$, Prange $H$, Schneider D, Weimar C, Wartenberg K, Schellinger PD, Bohn M, Becker H, Wegrzyn M, Jähnig P, Herrmann M, Knauth M, Bähr M, Heide W, Wagner A, Schwab S, Reichmann H, Schwendemann G, Dengler R, Kastrup A, Bartels C, EPO Stroke Trial Group: Recombinant human erythropoietin in the treatment of acute ischemic stroke. Stroke 2009, 40:e647-e656.

4. Najjar SS, Rao SV, Melloni C, Raman SV, Povsic TJ, Melton L, Barsness GW, Prather K, Heitner JF, Kilaru R, Gruberg L, Hasselblad V, Greenbaum AB, Patel M, Kim RJ, Talan M, Ferrucci L, Longo DL, Lakatta EG, Harrington RA, REVEAL Investigators: Intravenous erythropoietin in patients with ST-segment elevation myocardial infarction: REVEAL: a randomized controlled trial. JAMA 2011, 305:1863-1872.

5. Prunier F, Bière L, Gilard M, Boschat J, Mouquet F, Bauchart JJ, Charbonnier $B$, Genée O, Guérin P, Warin-Fresse K, Durand E, Lafont A, Christiaens L, Abi-Khalil W, Delépine S, Benard T, Furber A: Single high-dose erythropoietin administration immediately after reperfusion in patients with ST-segment elevation myocardial infarction: results of the erythropoietin in myocardial infarction trial. Am Heart J 2012, 163:200-207.

6. Swedberg K, Young JB, Anand IS, Cheng S, Desai AS, Diaz R, Maggioni AP, McMurray JJ, O'Connor C, Pfeffer MA, Solomon SD, Sun Y, Tendera M, van Veldhuisen DJ, RED-HF Committees; RED-HF Investigators: Treatment of anemia with darbepoetin alfa in systolic heart failure. N Engl J Med 2013 368:1210-1219.

7. Ghali JK, Anand IS, Abraham WT, Fonarow GC, Greenberg B, Krum H, Massie BM, Wasserman SM, Trotman ML, Sun Y, Knusel B, Armstrong P, Study of Anemia in Heart Failure Trial (STAMINA-HeFT) Group: Randomized double-blind trial of darbepoetin alfa in patients with symptomatic heart failure and anemia. Circulation 2008, 117:526-535.

8. Singh AK, Szczech L, Tang KL, Barnhart H, Sapp S, Wolfson M, Reddan D, CHOIR Investigators: Correction of anemia with epoetin alfa in chronic kidney disease. N Engl J Med 2006, 355:2085-2098. 
9. Drüeke TB, Locatelli F, Clyne N, Eckardt KU, Macdougall IC, Tsakiris D, Burger HU, Scherhag A, CREATE Investigators: Normalization of hemoglobin level in patients with chronic kidney disease and anemia. N Engl J Med 2006, 355:2071-2084.

10. Tonia T, Mettler A, Robert N, Schwarzer G, Seidenfeld J, Weingart O, Hyde C, Engert A, Bohlius J: Erythropoietin or darbepoetin for patients with cancer. Cochrane Database Syst Rev 2012, 12, CD003407.

11. Sureshkumar KK, Hussain SM, Ko TY, Thai NL, Marcus RJ: Effect of high-dose erythropoietin on graft function after kidney transplantation: a randomized, double-blind clinical trial. Clin J Am Soc Nephrol 2012, 7:1498-1506.

12. Oh SW, Chin HJ, Chae DW, Na KY: Erythropoietin improves long-term outcomes in patients with acute kidney injury after coronary artery bypass grafting. J Korean Med Sci 2012, 27:506-511.

13. de SeigneuX S, Ponte B, Weiss L, Pugin J, Romand JA, Martin PY, Saudan P: Epoetin administrated after cardiac surgery: effects on renal function and inflammation in a randomized controlled study. BMC Nephrol 2012, 13:132.

14. Endre ZH, Walker RJ, Pickering JW, Shaw GM, Frampton CM, Henderson SJ, Hutchison R, Mehrtens JE, Robinson JM, Schollum JB, Westhuyzen J, Celi LA, McGinley RJ, Campbell IJ, George PM: Early intervention with erythropoietin does not affect the outcome of acute kidney injury (the EARLYARF trial). Kidney Int 2010, 77:1020-1030.

15. Wu WT, Hu TM, Lin NT, Subeq YM, Lee RP, Hsu BG: Low-dose erythropoietin aggravates endotoxin-induced organ damage in conscious rats. Cytokine 2010, 49:155-162.

16. Sølling C, Christensen AT, Nygaard U, Krag S, Frøkiaer J, Wogensen L, Krog J, Tønnesen EK: Erythropoietin does not attenuate renal dysfunction or inflammation in a porcine model of endotoxemia. Acta Anaesthesiol Scand 2011, 55:411-421.

17. Freddolino PL, Tavazoie S: The dawn of virtual cell biology. Cell 2012, 150:248-250.

doi:10.1186/s13054-014-0526-9

Cite this article as: Pearl: Erythropoietin and organ protection: lessons

from negative clinical trials. Critical Care 2014 18:526. 